\title{
A Somatic Cell Hybrid Panel and DNA Probes for Physical Mapping of Human Chromosome 7p
}

\author{
A. VortKamp, * U. Thias, * M. Gessler, * W. Rosenkranz, † P. M. Kroisel, † N. Tommerup, $\neq 1$ \\ G. KRÜGer, § J. Götz,§ L. Pelz,§ AND K.-H. GrzesChIK* \\ *Institut für Humangenetik der Universitát, Bahnhofstrasse 7, D-3550 Marburg, Federal Republic of Germany; \\ †Institut für Medizinische Biologie und Humangenetik der Universität, Harrachgasse 21/8, A-8010 Graz, Austria; \\ §Kinderklinik der Universität, Rembrandtstrasse 16/17, 0.2500 Rostock, Federal Republic of Germany; and \\ ¥J. F. Kennedy Institute, G. I. Landevej 7, DK-2600 Glostrup, Denmark
}

Received May 8, 1991; revised July 12, 1991

To identify by reverse genetics genes on the short arm of human chromosome 7 expected to be involved in the regulation of human craniofacial and limb development, we have set up a human mouse somatic cell hybrid panel that divides $7 p$ into 9 fragments. The breakpoints are defined by deletions or translocations involving one chromosome 7 in the cells of the human cell fusion partners. Particularly densely covered with these cytogenetic anchor points is the proximal area of $7 \mathrm{p}$ within and around $7 \mathrm{p} 13$. The number of cytogenetic mapping points within proximal 7p could be increased by four, using two diploid human cell lines with small interstitial deletions in this region for dosage studies. We used Southern blots of this panel to assign to 7q or subregions of $7 p$ more than 300 arbitrary DNA probes or genes that provide reference points for physical mapping of $7 p$. Three reciprocal translocations with one of the breakpoints in 7p13 mark the location of a gene involved in Greig cephalopolysyndactyly syndrome. To define an area in which we could identify candidates for this developmental gene, we established a macrorestriction map using probes flanking the putative gene region. The Greig translocations were found to be located within a 630-kb NotI restriction fragment. 1991 Academic Prese, Inc.

\section{INTRODUCTION}

Detailed physical and genetic maps are one prerequisite for the search for particular human genetic disease loci by reverse genetics. Unless microscopically visible mutations guide the way to the gene as was the case in DMD (Boyd et al., 1986), several open reading frames in a chromosome region identified by linkage studies must be considered as candidate genes and

\footnotetext{
${ }^{1}$ Present address: Department of Medical Genetics, Ullevaal Hospital, P.B. 1036 Blindern, 0315 Oslo, Norway.
}

analyzed individually (Estivill et al., 1987; Rommens et al., 1989).

It has been suggested that the short arm of human chromosome 7 carries a gene cluster involved in craniofacial and limb development (Brueton et al., 1988; Winter and Huson, 1988; Pohl et al., 1990). Particularly rewarding for a reverse genetics search in this area is the gene underlying the Greig cephalopolysyndactyly syndrome (GCPS) because cytogenetic peculiarities, two translocations and three deletions, affecting band 7p13 have been associated with this syndrome (Tommerup and Nielsen, 1983; Krüger et al., 1989; Wagner et al., 1990; Pettigrew et al., 1989). We had previously used cells from a Greig patient with a third translocation, $t(6 ; 7)$, involving a breakpoint in 7 p13 for gene mapping with somatic cell hybrids (Johannsmann et al., 1980). The syndrome consists of postaxial polydactyly of the hands, pre- and postaxial polysyndactyly of the feet, macrocephaly, prominent forehead, broad nasal bridge, and hypertelorism (Greig, 1926). Inheritance is autosomal dominant with complete penetrance but considerable intrafamilial variability (Temtamy and McKusick, 1969). A mouse model for the Greig syndrome may exist in the mutant extra-toes $(X t)$ (Johnson, 1967) and the probably allelic mutation anterior digit-pattern deformity (add) that has recently been described (Pohl et al., 1990). In addition to a complex abnormality of embryonic development, a fundamental disturbance of the process of ossification may be associated with GCPS (Brueton et al., 1988). Tommerup and Nielsen (1983) postulated a role of the gene(s) involved in this syndrome in neoplasia on the basis of the similarity of certain abnormalities to those that occur in the hereditary basal cell carcinoma syndrome.

Dominant mutations of a gene disturbing pattern formation in human and mouse and possibly predisposing to certain malignancies are of considerable gen- 
eral interest. Therefore in the course of our studies involving somatic cell hybrids as a means for physical mapping of $7 p$ we have focused on the dissection of the $7 \mathrm{p} 13$ region. We describe a mapping panel for $7 \mathrm{p}$, assign a large number of gene probes and arbitrary DNA fragments, and define a large restriction fragment that is likely to harbor the putative Greig gene region.

\section{MATERIALS AND METHODS}

\section{Somatic Cell Hybrids}

Somatic cell hybrids were constructed by fusing human fibroblasts containing translocations or deletions involving chromosome $7 \mathrm{p}$ with HPRT-negative RAG or A9 mouse cells using PEG 1640 (Koch Light) as described previously (Bender and Grzeschik, 1976). Clones containing chromosome 7 fragments were isolated by subcloning. The production of the primary hybrids from which the subclones IT A9 2-21-14, IT A9 2-18-9-7-11, Rag GN6, Ru Rag 4-13, and Ru Rag 6-19 were derived has been reported by Bauch et al. (1978).

The fibroblasts IT originate from a female Greig patient who was a carrier of a balanced translocation $46, \mathrm{XX}, \mathrm{t}(6 ; 7)(\mathrm{q} 12 ; \mathrm{p} 13)$ (Johannsmann et al., 1980). The fibroblasts RoH $[46, \mathrm{XX}, \mathrm{t}(6 ; 7)(\mathrm{q} 27 ; \mathrm{p} 13)$ (Krüger et al., 1989)] and $1863[46, \mathrm{XY}, \mathrm{t}(3 ; 7)(\mathrm{p} 21.1 ; \mathrm{p} 13)$ (Tommerup and Nielsen, 1983)] were from Greig patients as well. These patients were members of large families in which the syndrome was associated with the translocation chromosomes involving breakpoints in 7p13. The lymphoblast cells 4IRB and 3BC were established from Greig patients with small interstitial deletions in one of their chromosomes 7: 4IRB had a deletion (7p11.2-7p13) due to a de novo translocation 7;20, and 3BC had a de novo deletion (7p12.3-7p13) (Wagner et al., 1990). Fibroblasts GM $1696[46, \mathrm{X}, \mathrm{t}(\mathrm{X} ; 7)(\mathrm{q} 21 ; \mathrm{p} 22)], \mathrm{GM} 0044$ [46,XY,del(7) (p21.2p22.1), t(7;10) (7qter-7p21.2::10q11.21-10qter; 10pter-10q11.21::7p22.1-7pter)], GM 1356 [46,XX,t $(1 ; 7)(\mathrm{p} 34 ; \mathrm{p} 13)]$, and the lymphoblast cell lines GM 3162 and GM 3105 were obtained from the NIGMS Human Genetic Mutant Cell Repository (Camden, NJ). Hybrid 5387 3cl10 was a gift from Dr. C. Croce (Croce and Koprowski, 1974).

\section{DNA Probes}

The majority of DNA probes (series pFS) were isolated from a flow-sorted human chromosome 7 library in phage Charon 21A (LA07NS01) (Deaven et al., 1986). Plaques were screened according to Benton and Davis (1977) with either total genomic human or total genomic hamster DNA labeled with ${ }^{32} \mathrm{P}$ by random primed DNA labeling. Plaques that showed hy- bridization with human DNA only were picked and DNA was prepared from plate lysates (Helms et al., 1985). ${ }^{32} \mathrm{P}$-labeled phage inserts were used as probes for hybridization to genomic Southern blots of hybrid or lymphocyte DNA after prehybridization with an excess of unlabeled human placental DNA (Litt and White, 1985). Inserts that mapped to chromosome $7 \mathrm{p} 13$ were subcloned into $\mathrm{pBluescript} \mathrm{SK}^{-}$(Stratagene Inc.).

The origin of probes 4-18, 6-20, 6-31, 7-13, 9-2, 5-23, 7-2, and 7-6 has been described previously (Jobs et al., 1990). Clones pA89, pA116, pA117, pB4, pB36, pB69, pC105, pC111U, pC140, pE146L, pG179, SF4, TG38, TG121, TM60, TM66U, TM102L, TN34, TN122, TN157, TN200, TS93, and TS194 were gifts from Dr. L. C. Tsui, Toronto (Rommens et al., 1988). Additional probes were kindly provided by Collaborative Research Inc. (CRI-P137, CRI-pS207, CRI-R944: Donis-Keller et al., 1987), Dr. M. Cohen-Solal, Paris (pGAM 14: Mattei et al., 1989), Dr. N. Shimizu, Tokyo (pERP8: Kawasaki et al, 1988), or K. Kontula, Helsinki (pp12: Julkunen et al., 1988) or were obtained from the ATCC (pHERA64-1,EGFR, No. 57484 and phage 6, D7S11, No. 57030).

\section{Southern Blot Analysis}

Genomic DNA was isolated according to standard procedures, digested with restriction enzymes $(3 \mathrm{U} /$ $\mu \mathrm{g}$ ) as recommended by the supplier (Boehringer Mannheim), and separated on $0.8 \%$ agarose gels. For PFGE, DNA was prepared from freshly harvested lymphoblasts or fibroblasts embedded in agarose blocks according to Smith et al. (1987). Blocks containing $1 \times 10^{6}$ cells were digested with rare-cutter enzymes as described by Van Ommen and Verkerk (1986). Southern blots were prepared using Biodyne A nylon membranes (Pall, Dreieich, Germany) and a vacublot transfer system (Pharmacia).

Blots for gene dosage studies were carefully controlled for loading of equal amounts of DNA, and autoradiograms were independently evaluated by two persons.

Hybridization was carried out in $5 \times$ SSC, $5 \times$ Denhardt's, $0.5 \%$ SDS, $7 \%$ dertran sulfate, and $100 \mu \mathrm{g} / \mathrm{ml}$ HSDNA at $65^{\circ} \mathrm{C}$ overnight. Filters were washed three times for $20 \mathrm{~min}$ in $0.2 \times \mathrm{SSC}, 0.1 \%$ SDS at $55-60^{\circ} \mathrm{C}$ and exposed for $1-5$ days at $-70^{\circ} \mathrm{C}$ with intensifying screens.

\section{Chromosome Walking}

Long insert phage clones for the 5-23 locus were isolated from a human MboI partial digest library in EMBL3 (provided by S. Orkin) as described previously (Gessler and Bruns, 1988). A NotI site which was detected within cloned DNA is also cut in geno- 


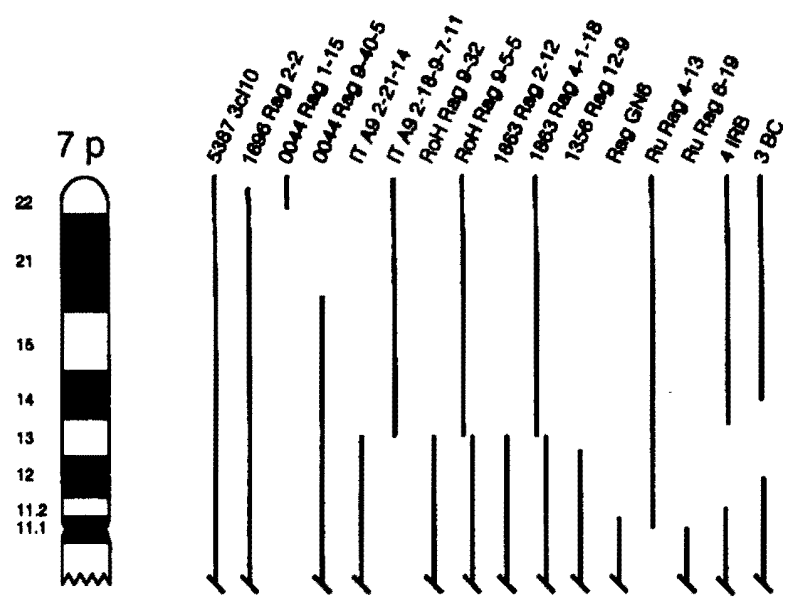

FIG. 1. Schematic representation of the chromosome $7 \mathrm{p}$ somatic cell hybrid mapping panel. The chromosome 7 content of each hybrid is indicated by the vertical bars. Hybrid $53873 \mathrm{cl} 10$ contains only a single human chromosome. The bars labeled 4IRB and $3 \mathrm{BC}$ represent hemizygous interstitial deletions of chromosome $7 \mathrm{p}$ material in lymphoblasts.

mic DNA, and a 2-kb HindIII/Notl fragment (p523ES6HN2) identified the adjacent NotI fragment upon PFGE analysis.

\section{RESULTS}

\section{Development of Somatic Cell Hybrids}

The somatic cell hybrid mapping panel used for these studies is shown schematically in Fig. 1. The chromosome 7p material present in each hybrid is represented by the vertical lines. $53873 \mathrm{cl} 10$ is used as a control because it contains an intact chromosome 7 as the only human material. For hybrids carrying translocations, available complementary clones were included (IT, Ru). In the fibroblasts, GM 0044 material from 7p21.1-p22.1 was lost completely due to the translocation event. The two complementary clones therefore define three regions (pter-p22.1, p22.1p21.1, p21.1-qter). From the RoH and 1863 hybrids clones containing both translocation fragments but no intact chromosome 7 were included in order to detect minor deletions resulting from the translocation process. Clone Rag GN6 was the product of a spontaneous deletion during the cell fusion process. The deleted chromosomes of the lymphoblastoid lines 4IRB and $3 B C$ are included in Fig. 1 although they were not separated from their intact counterparts by cell hybrid formation. Assignment to the deleted area was achieved by double hybridization of both probe 5-36 (D7S28) known to be localized on 7q (Jobs et al., 1990) and various 7p test probes to genomic Southern blots of 3BC and 4IRB DNA and DNA from diploid controls with two intact chromosomes 7 (Fig. 2). The relative intensities of the $7 q$ and $7 p$ bands were compared. Bands with half the intensity of the disomic controls indicated a localization in the monosomic region.

\section{Regional Mapping on 7p}

Of the 300 probes from the pFS series hybridized to the panel, 113 of them were localized on various regions of $7 p$ (Fig. 3). The others were assigned to $7 q$ (data not shown). Other probes previously assigned to $7 \mathrm{p}$ by Jobs et al. (1990) and Rommens et al. (1988) were ordered in a detailed map of 7p (Fig. 3). Particularly interesting with respect to the position of the Greig locus are TG38 and 5-23 immediately flanking the translocation breakpoints.

Wagner et al. (1990) assigned the locus for the muscle-specific form of phosphoglycerate mutase (PGAM2) missing in both deletions 4IRB and $3 B C$ to the region 7p12.3-p13, and the locus for the epidermal growth factor receptor (EGFR) between the proximal breakpoints of 3BC and 4IRB. Drabkin et al. (1989) prepared a hybrid clone from the same Greig patient's cells as 1863 Rag 2-12 carrying the complementary fragment. Their clone was used to assign CRI-P137 and CRI-pS207 distal and CRI-R944 and EGFR proximal to the translocation breakpoint of fibroblasts 1863 in $7 \mathrm{p} 13$. Our results provide a definitive order for the genes in this region, with EGFR located most centromeric between breakpoint Rag GN6 and 3BC (proximal); then PGAM and IBP1, an insulinlike growth factor binding protein detected by probe pp12 in the next interval up to 1356 Rag 12-9; followed by CRI-R944 between this breakpoint and the Greig translocation region. Probes CRI-P137 and CRI-pS207 map distal to this region separated by the distal deletion boundary of 4IRB. Our assignment of CRI-pS207, a probe linked within $160 \mathrm{~kb}$ to the

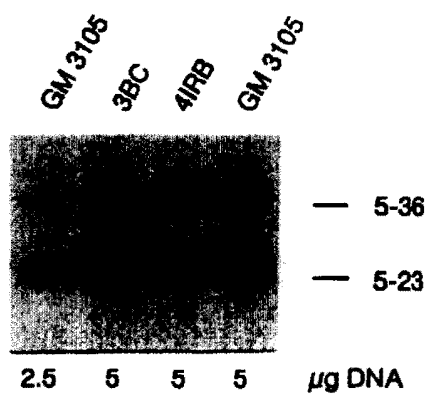

FIG. 2. Gene dosage analysis localizes probe 5-23 within the GCPS deletion of 4IRB and 3BC. A Southern blot filter containing EcoRI-digested DNA of the two GCPS deletion cell lines and a normal human control cell line (GM 3105) was simultaneously hybridized with probes 5-23 and 5-36. Probe 5-36 derived from 7q was used as an internal control. The lane with $2.5 \mu \mathrm{g}$ of GM $3105 \mathrm{DNA}$ provided a $50 \%$ intensity signal for comparison. 


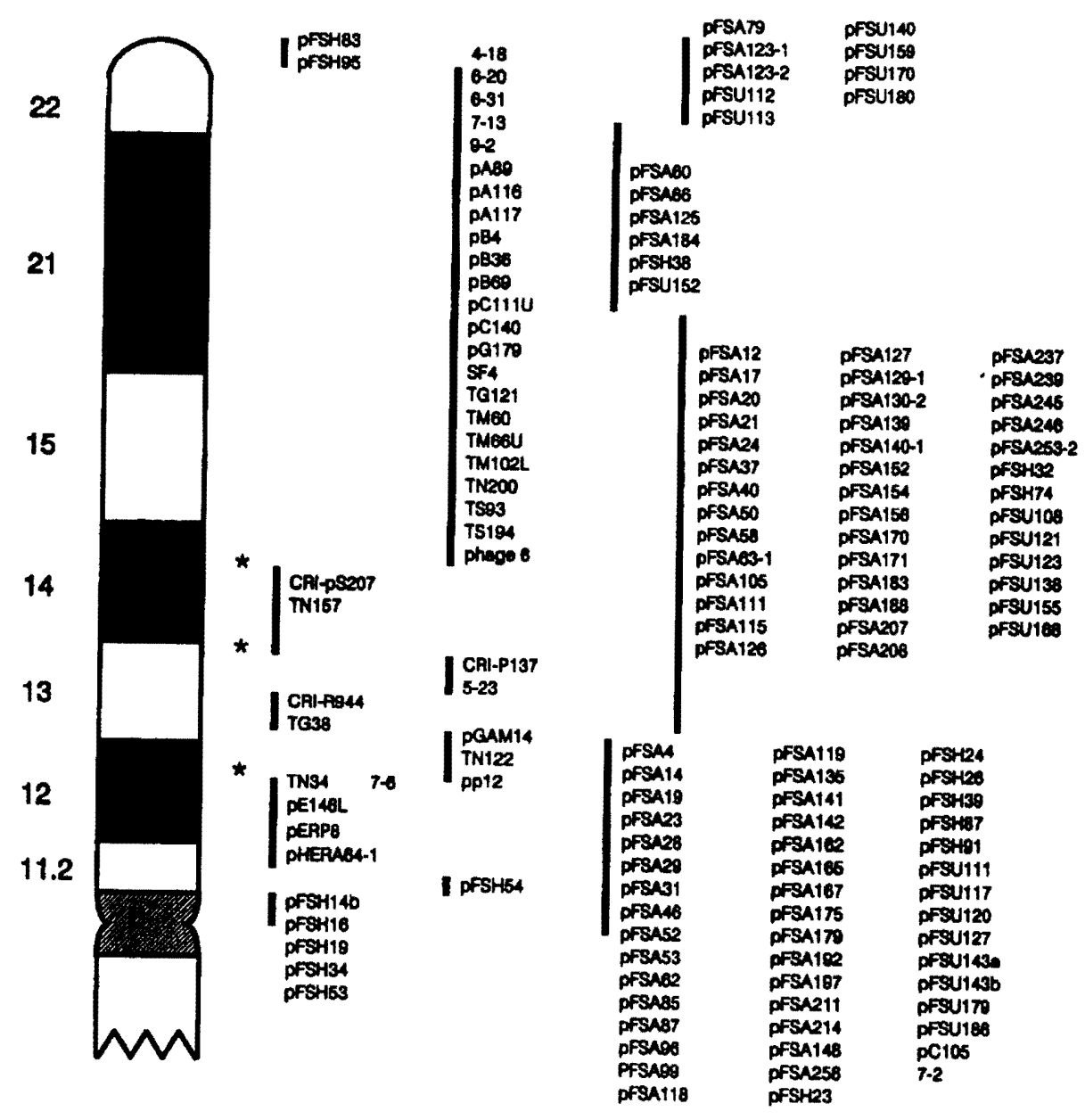

FIG. 3. Localization of DNA probes on 7p. The regions indicated by vertical bars are defined by the 7p breakpoints in the cells of the panel shown in Fig. 1. Asterisks indicate deletion breakpoints analyzed by dosage blot analysis.

TCRG region (Drabkin et al., 1989), is in concordance with the results of Wagner et al. (1990). None of the probes described here mapped in between the three translocation breakpoints in Greig patients.

\section{Pulsed-Field Analysis}

From the segregation data on our hybrid clones, CRI-P137 and 5-23 were found immediately distal and CRI-R944 and TG38 proximal to the putative Greig locus. Since the CRI probes mapped genetically at a distance of $0 \mathrm{cM}$ (Donis-Keller et al., 1987) we attempted to span the Greig region with a macrorestriction map. Drabkin et al. (1989) did not detect any comigrating pulsed-field fragments by hybridization with CRI-P137 and CRI-R944. We also did not find any common fragments detected by these probes in digests of the lymphoblastoid cells GM 3162 with the rare-cutter enzymes BssHII, KspI, MluI, and NotI. The proximal probes CRI-R944 and TG38 share common fragments with all four enzymes. The 308-kb
KspI fragment is partially cut into two fragments of 220 and $88 \mathrm{~kb}$ recognized by CRI-R944 and TG38, respectively. The order and relative position of the individual fragments (Fig. 4b) were established by double digests and combinations with more frequently cutting enzymes like $S a l l$ and SfiI (data not shown). CRI-P137 and 5-23 detect a common 1420-kb NotI/MluI partial digest fragment, but are located at least $850 \mathrm{~kb}$ from each other (data not shown). To facilitate PFGE mapping we scanned the vicinity of the four probes for the presence of $\mathrm{CpG}$ islands. Probe 5-23 turned out to be located less than $20 \mathrm{~kb}$ from a NotI site. By chromosome walking in a human genomic EMBL3 library, probe 5-23ES6HN2, a 2-kb NotI/HindIII subfragment that detects the adjacent genomic NotI fragment, was isolated. This probe and CRI-R944/TG38 share a common 630-kb NotI fragment in fibroblast (GM 0044) and lymphoblast (GM 3162) DNA (Fig. 4a). Its position within a 1120-kb BssHII fragment is shown in Fig. 4b. As these probes are located on opposite sides of all three GCPS trans- 


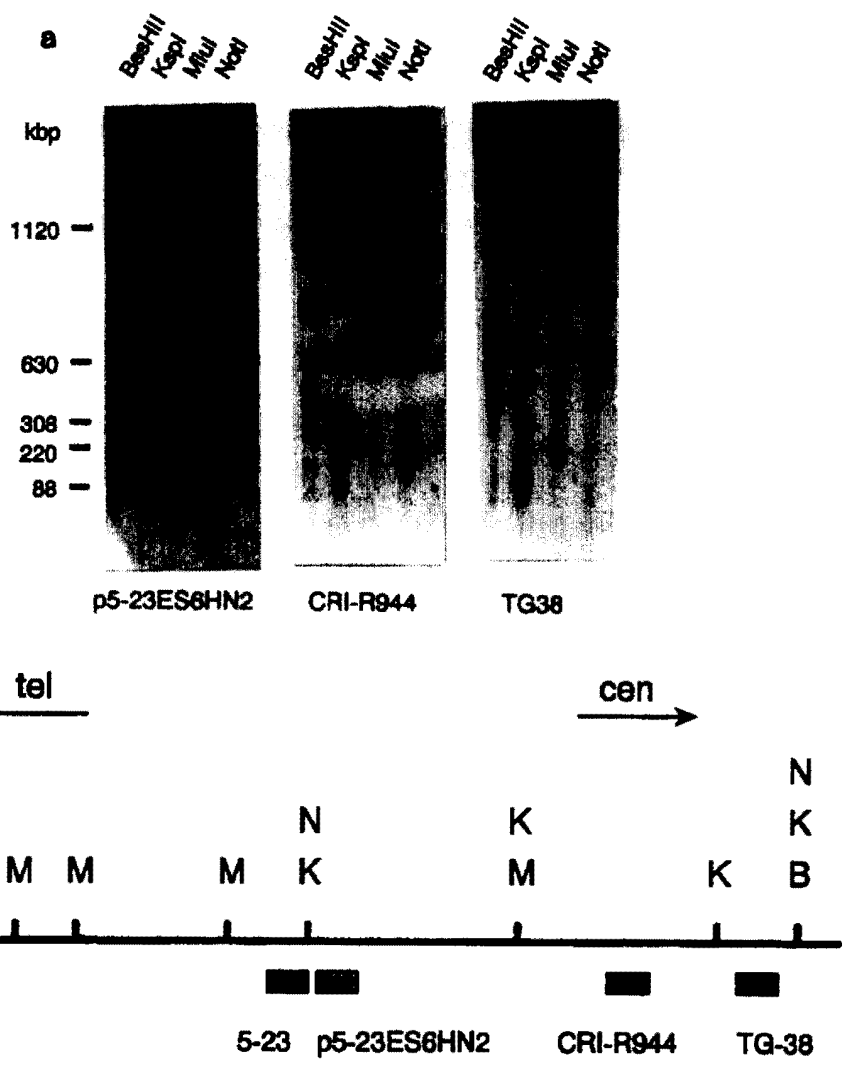

FIG. 4. Probes flanking the Greig translocation breakpoints are located within 630 kb. (a) Southern blot analysis of BssHII-, Kspl-, MluI-, and NotI-digested DNA isolated from lymphoblastoid cell line GM 3162 and hybridized to p5-23ES6HN2, CRI-R944, and TG38, respectively. The gel was run at $200 \mathrm{~V}$ with pulse time ramping $60-90 \mathrm{~s}$ for $24 \mathrm{~h}$ at $14^{\circ} \mathrm{C}$. Size markers used were $S$. cerevisiae chromosomes and EMBL 3A concatemers. (b) Restriction map of the region covering the putative GCPS locus in 7p13 flanked by probes 5-23 and CRI-R944/TG38. The precise positions of CRI-R944 and TG38 within their respective restriction fragments have not been determined. B, BssHII; K, KspI; M, MluI; N, NotI. Arrows point toward centromere and telomere.

locations, the chromosomal breakpoints must fall within this NotI fragment. This conclusion could be confirmed by PFGE analysis of fibroblast DNA from GCPS patients. In addition to the 630 -kb fragment, probe CRI-R944 detected altered NotI fragments of 750 and $900 \mathrm{~kb}$ in $\mathrm{RoH}$ and 1863, respectively, whereas p5-23ES6HN2 hybridized to additional 580and $370-\mathrm{kb}$ NotI fragments (Fig. 5). We could not detect an altered NotI fragment in IT. Such a fragment, however, could be too large to be resolved under our PFGE conditions.

\section{DISCUSSION}

The development of the mapping panel described in this report serves two purposes: (i) it allows compartmentalization of $7 p$ into regions approximately equivalent in size to low-resolution cytogenetic bands; (ii) it dissects band 7p13 into six fragments. Our strategy toward the construction of a physical map of $7 p$ is to fill the individual compartments with about 50 arbitrary seed probes each from sorted libraries as foci from which YAC contigs can grow. The probes mapped in this study are an important step toward this end. Furthermore, these probes will be valuable tools for the characterization of additional genes on chromosome 7p such as the gene for craniosynostosis postulated in 7p21 (Motegi et al., 1985).

The region around the GCPS locus on 7p13 is densely covered with cytogenetic breakpoints that allow a fine resolution of probe order. Probes CRI-R944 and 5-23ES6HN2 are the closest flanking markers for the GCPS region, less than $630 \mathrm{~kb}$ from each other. They will be used for the isolation of genomic clones that can be screened for expressed sequences. Other disorders that should be considered in these studies are the acrocallosal syndrome, which is considered a recessive allele of GCPS, and the mouse mutant extra toes because of the similar limb and craniofacial malformations (Schinzel, 1982; Hendriks et al., 1990).

TCRG and the gene for biliverdin reductase (BLVR) flank the Greig region in human $7 \mathrm{p} 13$ (Peters et al., 1989). BLVR has previously been assigned to the region between the breakpoint in the IT cells (in 7p13) and the centromere (Meera Khan et al., 1983). The breakpoint had been indicated as $7 \mathrm{p} 14$ due 


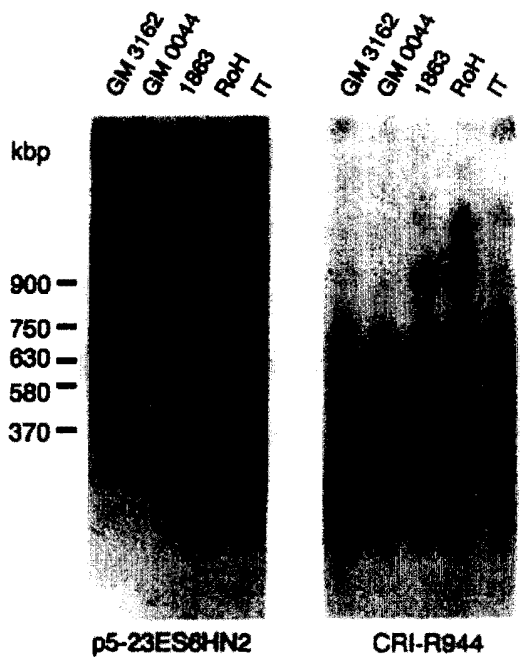

FIG. 5. Probes flanking the Greig locus detect different additional bands (arrowheads) in Southern blot analysis of NotI-digested DNA isolated from fibroblasts of Greig translocation carriers 1863 and RoH. GM 3162 is a lymphoblastoid cell line, GM 0044 a fibroblast control. The gel was run at $200 \mathrm{~V}$ with pulse time ramping $60-90$ s for $24 \mathrm{~h}$ at $14^{\circ} \mathrm{C}$.

to inadequate resolution of cytogenetic preparations. In mouse the Tcrg locus is linked on chromosome 13 to extra toes $(X t)$, which is most probably the mouse homologue of the Greig syndrome (Winter and $\mathrm{Hu}$ son, 1988). The gene for the mouse biliverdin reductase, Blvr, however, is located on chromosome 2, closely linked to small eye (Sey) and limb deformity (ld) (Peters et al., 1989). From these observations Peters and co-workers (1989) suggested that there was a cluster of genes for limb and craniofacial development in a common ancestor of human and mouse linked to TCRG and BLVR that has become broken up in the mouse. This would imply that the synteny of TCRG, GCPS, and BLVR in human represented the ancestral cluster. The human homologue to Sey, however, has recently been shown to be aniridia on chromosome 11p, and the human homologue to limb deformity is expected to be on chromosome 15 near the $\beta_{2}$-microglobulin gene which is closely linked to $l d$ also in the mouse (Glaser et al., 1990; van der MeerDe Jong et al., 1990).

Tommerup and Nielsen (1983) suggested that the bony abnormalities shared by the Greig syndrome and the hereditary basal cell carcinoma syndrome (BCNS) indicate a common pathogenic mechanism for these disorders. The development of medulloblastoma in one family member with the $3 ; 7$ translocation is discussed by these authors in view of the occurrence of medulloblastoma in BCNS.

The possibility of a close neighborhood of a series of genes involved in human development and neoplasia in 7 p13 suggests that it is worthwhile to attempt a complete map of all expressed sequences in the approximately $5 \mathrm{Mb}$ of this region. Our panel and the new probes described here will be very helpful in this enterprise.

\section{ACKNOWLEDGMENTS}

We thank L.-C. Teui, A. Jobs, Collaborative Research Inc., M. Cohen-Solal, N. Shimizu, and K. Kontula for DNA probes; C. Croce for hybrid cells; and S. Orkin for an aliquot of the human EMBL3 library. This work was supported by a grant from the Deutsche Forschungsgemeinschaft (Gr 373/14-1). N.T. is supported by the Danish Cancer Society and the Danish Human Genome Program.

\section{REFERENCES}

1. BAUCh, W., HeLllkUHL, B., AND GRTESChiK, K. H. (1978). Regional assignment of the gene for human $\beta$-glucuronidase by the use of human-mouse cell hybrids. Cytogenet. Cell Genet. 22: 434-436.

2. BENDER, K., AND GRakschiK, K. H. (1976). Possible asgignment of the glyoxalase I (GLO) gene to chromosome 6 using man-mouse somatic cell hybrids. Humangenetik 31: 341345.

3. BENTON, W. D., AND DAvis, R. W. (1977). Screening lambda gt recombinant clones by hybridization to single plaques in situ. Science 186: 180 .

4. BOYD, Y., BuCKLs, V., HOLT, S., MunRo, E., Hunter, D., AND CRAIG, I. (1986). Muscular dystrophy in girls with X;autosome translocations. J. Med. Genet. 23: 484-490.

5. BRueton, L., Huson, S. M., WINTER, R. M., AND WIILAAMSON, R. (1988). Chromosomal localization of a developmental gene in man: Direct DNA analysis demonstrates that Greig cephalosyndactyly maps to 7p13. Am.J. Med. Genet. 31: 799804.

6. Croce, C. M., AND KoprowskI, H. (1974). Somatic cell hybrids between mouse peritoneal macrophages and SV40 transformed human cells. I. Positive control of the transformed phenotype by the human chromosome 7 carrying the SV40 genome. J. Exp. Med. 140: 1221-1229.

7. Deaven, L., Van Dilla, M., Barthold, M. F., Carrano, A. V., Cram, L. S., Fuscoe, J. C., Gray, J. W., HudkBrand, C. E., Moyzas, R. K., AND Prrlaman, J. (1986). Construction of human chromosome-specific DNA libraries from flowsorted chromosomes. Cold Spring Harbor Symp. Quant. Biol. 51: 159-167.

8. Donis-Kruler, H., Grien, P., Hehlms, C., Cartinhour, S., Wedrfenbach, B., Stephens, K., KerTh, T. P., Bowden, D. W., SmTth, D. R., LANDER, E. S., BotrgTkin, D., AKoTs, G., Rrodikgr, K. S., Gravtus, T., Brown, V. A., Rising, M. B., Parker, C., Powers, J. A., Watt, D. E., Kaumpman, E. R., Brickrar, A., Phipps, P., Mullear-Kahle, H., FulTON, T. R., NG, S., SchumM, J. W., Braman, J. C., KNOWLTON, R. G., BARKer, D. F., Crooks, S. M., Lincoln, S. E., DAIIY, M. J., AND ABRAfaMgon, J. (1987). A genetic linkage map of the human genome. Cell 51: 319-337.

9. Drabkin, H., Sage, M., Helms, C., Grike, P., Gemmml, R., Smith, D., Erickson, P., Hart, I., Frraugon-Smith, A., RUDDLe, F., AND TOMMERUP, N. (1989). Regional and physical mapping studies characterizing the Greig polysyndactyly $3 ; 7$ chromosome translocation $(3 ; 7)($ p21.1;p13). Genomics 4: 518-529. 
10. Estivill, X., Farrall, M., Scamblek, P. J., Betl, G. M., Hawleg, K. M. F., Leuch, N. J., Bateg, G. P., KruYkr, H. C., Fredorrick, P. A., Stanter, P., Watson, E. K., WnLIMMSON, R., AND WAINWRIGHT, B. J. (1987). A candidate for the cystic fibrosis locus isolated by selection for methylationfree islands. Nature 326: 840-845.

11. GesslrkR, M., AND BruNs, G. A. P. (1988). Molecular mapping and cloning of the breakpoints of a chromosome 11p14.1-11p13 deletion associated with the AGR syndrome. Genomics 3: 117-123.

12. Glaser, T., LANE, J., AND Housman, D. (1990). A mouse model of the aniridia-Wilms tumor deletion syndrome. Science 250: 823-827.

13. Grarg, D. M. (1926). Oxycephaly, Edinburgh Med. J. 33: 189-218.

14. Helms, C., Graham, M. Y., Dutchik, J. E., and Olson, M. V. (1985). A new method for purifying lambda DNA from phage lysates. DNA 4: 39-49.

15. HENDRIKS, H. J. E., BRUNNER, H. G., HAMGEN, T. A. M., AND HAMEL, B. C. J. (1990). Acrocallosal syndrome. Am. J. Med. Genet. 35: 443-446.

16. Jobs, A., Klanin-Bölting, D., Jander, A. S., Drueset, A., OLEK, K., AND GRARSCHIK, K. H. (1990). Regional assignment of 41 human DNA fragments on chromosome 7 by means of a somatic cell hybrid panel. Hum. Genet. 84: 147-150.

17. Johanngmann, R., Schwinger, E., and Grueschik, K.-H. (1980). Assignment of the gene locus for human phosphoglucomutase-3 to chromosome 6q12-qter. Ann. Genet. 23: 1214.

18. Johnson, D. R. (1967). Extra-toes: A new mutant gene causing multiple anomalies in the mouse. J. Embryol. Exp. Mor. phol. 17(3): 543-581.

19. JULKUNEN, M., KOISTINEN, R., AALTO-SETÄLA, K., SeppXlä, M., JXNne, O. A., ANd Kontula, K. (1988). Primary structure of human insulin-like growth factor binding protein/placental protein 12 and tissue-specific expression of its mRNA. FEBS Lett. 236: 295-302.

20. Kawasaki, K., KUdoh, J., OMOTo, K., aND ShImzU, N. (1988). Megabase map of the epidermal growth factor (EGF) receptor gene flanking regions and structure of the amplification units in EGF receptor-hyperproducing squamous carcinoma cells. Jpn. J. Cancer Res. 79: 1174-1183.

21. KL.zBE, R. J., Chen, T. R., AND RUdDLE, F. (1970). Controlled production of proliferating somatic cell hybrids. J. Cell Biol. 45: 74-82.

22. KrÜger, G., GÖTZ, J., Kvist, U., DUNKER, H., ERTURTH, F., PELZ, L., AND ZECH, L. (1989). Greig syndrome in a large kindred due to reciprocal chromosome translocation $\mathrm{t}(6 ; 7)(\mathrm{q} 27 ; \mathrm{p} 13)$. Am. J. Med. Genet. 32: 411-416.

23. LITT, M., AND WHITE, R. L. (1985). A highly polymorphic locus in human DNA revealed by cosmid derived probes. Proc. Nath Acad. Sci. USA 82: 6206-6210.

24. LyON, M. F. (1988). Mouse chromosome atlas. Mouse Newslett. 81: $20-41$.

25. Mattei, M. G., Castella-Escora, J., Ojictus, D., Passage, E., VALENTIN, C., AND COHEN-SOLAL, M. (1989). In situ mapping of the phosphoglycerate mutase muscular form to the human chromosome 7. Cytogenet. Cell Genet. 61: 1041.

26. Mgera Khan, P., Wijnen, M. M., Wingen, J. Th., and Grazschro, K. H. (1983). Electrophoretic characterization and genetics of human biliverdin reductase (BLVR, EC 1.3.1.24): Assignment of BLVR to the p14-cen region of hu- man chromosome 7 in mouse-human somatic cell hybrids. Biochem. Genet. 21: 123-133.

27. Motegi, T., Ohuch, M., Ohtaki, C., Fujtwara, K., Enomoto, S., Hasegawa, T., Kishi, K., and Hayakawa, $H$. (1985). A craniosynostosis in a boy with a del(7)(p15.3p21.3): Assignment by deletion mapping of the critical segment for craniosynostosis to the mid-portion of 7p21. Hum. Genet. 71: 160-162.

28. Petrers, J., Ball, S. T., and Demim.nng, A. Von (1989). Localization of Blvr, biliverdin reductase, on mouse chromosome 2. Genomics 5: 270-274.

29. Pettigrew, A. L., Grkisnberg, E., Lkobettrar, D. H., AND CAskgy, C. T. (1989). Greig syndrome associated with an interstitial deletion of 7p: Confirmation of the localization of Greig syndrome to 7p13 (Abstract). Am. J. Hum. Genet. (Suppl.) 45: A87.

30. Pohl, T. M., Mattei, M. G., AND RÜtrer, U. (1990). Evidence for allelism of the recessive insertional mutation add and the dominant mouse mutation extra-toes (Xt). Development 110: 1153-1157.

31. Rommens, J. M., Zkngerling, S., Burns, J., Melmer, G., KerReg, B.-S., Plavisic, N., Zigica, M., Kennedy, D., MarKIEWICZ, D., RozanarizL, R., RIORDAN, J. R., BuCHWALd, M., AND Tsur, L.-C. (1988), Identification and regional localization of DNA markers on chromosome 7 for the cloning of the cystic fibrosis gene. Am. J. Hum. Genet. 43: 645-663.

32. Rommans, J. M., Januzzi, M. C., AND Kerkm, B. S. (1989). Identification of the cystic fibrosis gene: Chromosome walking and jumping. Science 245: 1059-1065.

33. Schinzar, A. (1982). Acrocallosal syndrome (Editorial). Am. J. Med. Genet. 12: 201-203.

34. SMith, C. L., LAWrance, S. K., Gillasipte, G. A., Cantor, C. R., Weissman, S. M., AND Coltuns, F. S. (1987). Strategies for mapping and cloning macroregions of mammalian genomes. In "Methods in Enzymology" (M. Gottesman, Ed.), Vol. 151, pp. 461-489, Academic Press, New York.

35. Temtamy, S., AND McKusick, V. A. (1969). Synopsis of hand malformations with particular emphasis on genetic factors. Birth Defects Orig. Artic. Ser. 6(3): 125-184.

36. TOMMERUP, N., AND NIELSEN, F. (1983). A familial reciprocal translocation $t(3 ; 7)(p 21.1 ; p 13)$ associated with the Greig polysyndactyly-craniofacial anomalies syndrome. Am.J. Med. Genet. 16: 313-321.

37. TsuI, L. C., AND FARALL, M. (1990). Report of the committee on the genetic constitution of chromosome 7. Cytogenet. Cell Genet. 55: 122-127.

38. Van Der Mrigr-De Jong, R., Dickingon, M. E., Woychik, R. P., Sturas, L., Hetharington, C., AND Hogan, B. L. M. (1990). Location of the gene involving the small eye mutation on mouse chromosome 2 suggests homology with human aniridia 2 (AN2). Genomics 7: 270-275.

39. VAN OMmEN, G. J. B., AND VERKKBRK, J. M. H. (1986). Regtriction analysis of chromosomal DNA in a size range up to two million base pairs by pulsed field gradient electrophoresis. In "Analysis of Human Cenetic Diseases" (K. Davies, Ed.), pp. 113-133, IRL Press, Oxford.

40. Wagner, K., Krotset, P. M., AND ROSENKRANZ, W. (1990). Molecular and cytogenetic analysis in two patients with microdeletions of $7 \mathrm{p}$ and Greig syndrome: Hemizygosity for PGAM2 and TCRG genes. Genomics 8: 487-491.

41. Winter, R. M., AND Huson, S. M. (1988). Greig cephalopolysyndactyly syndrome: A possible mouse homologue (Xt-Extra Toes). Am. J. Med. Genet. 31: 793-798. 